\title{
Effectiveness of Internship in Fostering Learning: The Case of African Rural University
}

\author{
Florence Ndibuuza \\ African Rural University, Kagadi-Kibaale, Uganda
}

\begin{abstract}
Internship is deemed to be a prerequisite for a 21 st Century graduate to survive in the world of work. It's on the basis of this that this study sought to establish the effectiveness of internship in respect to learning in the field among undergraduates of African Rural University. The quantitative survey involved 23 students and 53 community members who filled a questionnaire and an interview guide respectively. Data analysis involved the use of percentages, means and multiple regression. The results of the study revealed that the three independent variables: cognitive, behavioral, and environmental learning experience (CLE, BLE and ELE) were not correlates of internship. It's upon this background that it was recommended that the key players of the university ought to lay undue emphasis on enhancing CLE, BLE, and ELE, rather effort should be put on other elements to learning.
\end{abstract}

Keywords: internship, learning, cognitive, behavioral and environmental experience

\section{Introduction}

Internship has been associated with several benefits to all key concerned stakeholders including the intern, academic institution and the employer. Accordingly studies (e.g., Steffen, 2010; Bukaliya, 2012; Papadimitriou, 2014) highlighted that internship provides authentic work experience to students. The institution is said to benefit through the increased cooperation and rapport with the internship organization, Bukaliya (2012) yet (Neugebauer, 2009; Steffen, 2010) mentioned that many employers use internship as the main tool for recruiting new talent. There are quite a number of studies that have looked into the aspect of internship. For example, Kamulegeya, Kizito, and Balidawa (2012) looked into the Ugandan medical and health sciences interns' infection and control knowledge and practice, Chinomona and Surujhal (2012) addressed the influence of student's internship on their self-improvement and professionalism in respect to South Africa just like Taylor and Govender (2013) and Bama and Issy (2013) investigated education and training for the workplace and the graduate employability in cape town with specific reference to the environmental internship programme respectively.

The perception of the preparedness of medical graduates to take on internship responsibilities in low resource hospitals in Kenya was looked into by Muthaura and Khamis (2013) yet Papadimitriou (2014) looked into high school student's perception of their internship experience and the related impact on their career choices and changes. Important to note is that the mentioned studies were either done in contexts outside Africa or East Africa and those done with in Uganda were in the medical field. This leaves room for the study to look into the Education field. In addition, a study like Papadimitriou (2014) was done in respect to high school 
students which leaves room for this study to also consider university students. This paper therefore relates to internship in African Rural University (ARU) a university in Uganda, East Africa.

ARU is the first non-denominational community and value based all-women University. It was founded by Uganda Rural Development and Training Programme an indigenous Non-Government Organization (NGO). ARU is registered under the Government of Uganda Companies Act CAP 110 as a Company Limited by Guarantee. ARU was licensed by National Council for Higher Education in March 2011, number PL 017, Atwaru (2014). ARU as an all-women's university admits female students for academic and practical purposes, recognizing and awakening the intrinsic value of women as a teachers, organizers, producers (reproductive and productive), political and visionary leaders, peace makers, assertive manager and above all humanist (URDT, 2013).

In the quest to extend experiential learning to the students characteristic of a good 21st century graduate, ARU requires learners to undergo one year of internship in addition to a one month Village Practicum under its four year programme of Technologies for Rural Transformation. The internship introduces students to real life experience and prepares them for leadership in community driven development programmes in lieu of the Uganda Rural Development and Training Programme (URDT) Epicenter Strategy (ARU, 2014). Students are guided by both field and faculty mentors throughout the entire period as they learn, discover and build their knowledge bases in relation to rural transformation. ARU uses a mentorship approach to internship in that the university is fully involved in placements, mentoring, student's guidance and mentoring throughout the internship period alongside the field supervisor. The ARU Internship Report (ARU, 2014/2015) notes that the internship encourages self-discovery, builds confidence and supports learning using systems thinking and the principles of the creative process that enhance sustainable development. However, regardless of how good the internship is portrayed, the university never evaluated the internship after the pioneer group of 2014/2015. The ARU Internship Report (ARU, 2014/2015) clearly highlighted among other things the evaluation of the internship as one of its key out puts; however, a comprehensive evaluation was not done. It's on the basis of this that the study looked into the effectiveness of the internship among the pioneer undergraduate students as the units of analysis.

\section{Theoretical Base}

The study is anchored on the Social Cognitive Theory (SCT) advanced by Albert Bandura in 1977. According to Denler, Wolters, and Benzon (2014), the theory portends that learning occurs in social contexts and much of what is learned is gained through observation. For learning to occur, an individual's interpersonal experience has to converge with the behavioral determinants and environmental factors. In the person's environment interaction, human beliefs and ideas are modified by external factors, cognitive processes of a person affect his or her behavior and one's behavior can modify the environment (Bandura, 2011). According to Nebavi (2012) therefore, a person's ongoing functioning is a product of a continuous interaction between cognitive, behavioral and contextual factors. Thus the theory relates internship to learning through cognitive, behavioral and environmental learning aspects. The three variables are posited to be positive correlates of internship.

\section{Related Literature}

\section{Cognitive Learning as a Covariate of Internship}

Sincero (2011) defined cognitive learning as the acquisition and retention of information, reason, remember and relate. Quite a number of studies (e.g., Cord, Bowrey, \& Clements, 2010; El Tawil, Al Khal, 
Ahmed, \& Helmi, 2011; Raph \& Walker, 2014) positively related cognitive learning to internship in the different study situations. Cord et al. (2010) looked into accounting student's reflections on a regional internship programme, El Tawil et al. (2011) addressed the impact of traditional rotating internship on the cognitive skills of the trainees yet Raph and Walker (2014) looked at mentorship in the practicum from the post intern's perspective. Contrary results however were found in studies such as Rusnah, Yazkhiruni, Suhaily and Nurmazilah (2009) which looked into undergraduate internship attachment in accounting and Chen and Chen (2011) that addressed the influence of internship experience on the behavioral intention of college students in Taiwan. The controversial results created room to further test the hypothesis to the effect that:

H1: Cognitive learning is positively related to internship.

\section{Behavioral Learning as a Covariate of Internship}

Behavioral learning is observable and measurable aspects of human behavior that result from stimulus - response association made by the learners, Zhou and Brown (2014). This aspect has been positively related to internship through studies such as Rusnah et al. (2009) which looked into undergraduate internship attachment in accounting and Cord et al. (2010) that looked into accounting student's reflections on a regional internship programme. A study (Chen \& Chen, 2011) on the influence of internship experience on the behavioral intention of college students in Taiwan however deduced that behavioral learning was not a significant correlate of internship. The few studies considered do not give a clear picture of the relationship between the two variables thus the hypothesis ought to be examined further to the effect that:

$\mathrm{H} 2$ : Behavioral learning is positively related to internship.

\section{Environmental Learning as a Covariate of Internship}

The learning that occurs when a person interacts with a given context including people, animals and situations are what Lamberth (2010) considered as environmental learning. Studies (e.g., D'abate, Youndt, \& Wenzel, 2009; Cord et al., 2010; Kuijpers, Meijers, \& Gundy, 2010; Chen \& Chen, 2011) found environmental learning to be a significant correlate of internship. D'abate et al. (2009) was an empirical study on making the most of an internship, Cord et al. (2010) looked into accounting student's reflections on a regional internship programme, Kuijpers et al. (2010) addressed the relationship between the learning environment and career competencies of students in vocational education yet Chen and Chen (2011) was a study on the influence of internship experience on the behavioral intention of college students in Taiwan. However, some studies found environmental learning to be a negative correlate of internship. For example, Rusnah et al. (2009) which looked into undergraduate internship attachment in accounting and Kamulegeya, Kizito et al. (2012) which addressed the Ugandan medical and health science interns' infection knowledge and practice. The controversy in findings warrants further investigation to be done on the hypothesis to the effect that:

H3: Environmental learning is positively related to internship.

\section{Method}

\section{The Study Took the Quantitative Approach Was Generally Used for the Study in Respect to the Survey Design in Particular}

Data were collected on the key respondents using a self-administered questionnaire with the corresponding items on the three independent variables namely; cognitive, behavioral and environmental learning experience. The seven items under cognitive and behavioral learning were adapted from Chen and Chen (2011): $\alpha=0.78$ 
and $\alpha=0.82$ respectively. The seven items under environmental learning were adapted from Kuijpers et al. (2010): $\alpha=0.70$ and the ten items under internship as the dependent variable were adapted from (Ralphs \& Walker, 2014; Chen \& Chen, 2011) with $\alpha=0.75$. The sources of the items in the questionnaires were therefore reliable as all the alpha coefficients were above 0.5 (Tavakol \& Dennick, 2011). The validity of the tool was taken for granted based on Tavakol and Dennick's (2011) observation that a tool that is reliable is most likely to be valid. Yet still the tool was subjected to confirmatory reliability analysis after data collection. The second tool generically evolved from that of the first set of respondents of the study in respect to the mentioned variables.

\section{Sample}

With the self-administered questionnaire, data were collected from the interns of African Rural University, Kagadi-Kibaale District, Mid-western Uganda. The Faculty of Technologies for Rural Transformation (FTRT) was the center of focus for this study. FTRT offers a Bachelor of Science in Technologies for Rural Transformation. It admits a maximum of 30 undergraduates per academic year. While all the mandatory 30 students were targeted for the study, only 23 (76.7\%) responded. The second tool was subjected to the second set of respondents who included sub county chiefs, community development officers, at least two leaders of groups interns were working with and the faculty mentor attached to any of the 15 sub counties/Epicentres students worked with on internship. While all the 15 sub counties were targeted, only 14 Epicenters responded thus of the targeted 75 respondents, only 53 responded (70.7\%).

\section{Data Analysis}

The captured data were analyzed using percentages and means at the univariate descriptive level. At the multivariate inferential level, the three hypotheses were tested using multiple regression. The multiple regression model built was:

$$
\mathrm{IAF}=\beta_{1} \mathrm{CLE}+\beta_{2} \mathrm{BLE}+\beta_{3} \mathrm{ELE}
$$

where the dependent variable (DV), IAF was Internship. The constants $\beta_{1}, \beta_{2}$ and $\beta_{3}$ were coefficients of regression, each of which was postulated to be positive. The independent variables were as follows: CLE = cognitive learning experience, BLE = behavioral learning experience, and ELE = environmental learning experience.

\section{Findings}

\section{Background of the Respondents}

The details pertaining to the key set of respondents were as follows: in respect to entry into the university, the direct entrants dominated the sample with $91.3 \%$ while the ones that entered after diploma only constituted $8.7 \%$. In relation to the subcounty of attachment, Kagadi dominated the sample with $13 \%$, followed by Burora, Kyanaisoke, Muhoro, Mugarama, Nyamarunda, Kabamba and Pachwa with $8.7 \%$ and the least composition was registered by Rugashari, Nalweyo, Mabaale, Kyakabadiima, Kasambya and Bwanswa at $4.3 \%$. In terms of the language/s, interns were using with the locals, the group that used Runyakitara and English dominated the sample with $87 \%$ thus the ones that used other languages and English constituted only $13 \%$. In respect to age, the ones below 30 but above 25 were the majority with $60.9 \%$, followed by those above 30 with $21.7 \%$ and the least sample composition was of the group below 25 with $17.4 \%$. Regarding the number of villages of intervention, the group that worked with three to five villages dominated the sample with $69.6 \%$, followed by 
the group that worked with more than five villages with $26.1 \%$ and the group that worked with only two villages was the least represented with $4.3 \%$.

\section{The Dependent Variable: Internship}

Internship was split into two sections that is: academic mentors with six items $(\alpha=0.869)$ and field mentors with four items $(\alpha=0.889)$. Each item was scaled in such a way that: $1=$ "Strongly disagree", $2=$ "Disagree", 3 = "Undecided", 4 = "Agree" and 5 = "Strongly agree". The corresponding statistics are as given in Table 1.

Table 1

Statistics on Internship

\begin{tabular}{llll}
\hline & Mean & $\begin{array}{l}\text { Remark on } \\
\text { Internship }\end{array}$ & $\begin{array}{l}\text { Overall } \\
\text { remark }\end{array}$ \\
\hline Indicator of academic mentor & & \\
\hline My mentor was my role model & 3.68 & Undecided \\
My mentor had a positive attitude towards rural transformation which positively & 3.95 & Undecided \\
influenced my attitude & 4.32 & Agree & $\begin{array}{l}\text { Mean= } \\
\text { The mentor provided constructive feedback on my performance }\end{array}$ \\
The mentor encouraged me when field work became challenging & 4.18 & Agree & Agree) \\
The mentor closely followed my progress through frequent field visits & 3.90 & Undecided \\
The mentor was accessible and available for consultation & 4.33 & Agree & \\
\hline Indicator of field mentor & & & \\
\hline The mentor encouraged me with his/her personal experience & 4.05 & Agree & Mean = \\
The mentor respected and acknowledged my contribution in the Epicenter & 4.10 & Agree \\
The mentor challenged me with assignments as a way of improving my competence & 4.00 & Agree & (Agree) \\
The mentor filled my knowledge gaps & 3.86 & Undecided &
\end{tabular}

According to Table 1, the respondents generally agreed with the contribution of academic mentors in internship with a mean of 4.06 just as the same idea of agreement was registered against the contribution of the field mentors. The average index (IAF acronym for internship from the ten items in Table 1) had a mean $=4.03$, which pointed to the idea that majority of the respondents acknowledged the contribution of internship to their careers as rural transformation specialists.

\section{Independent Variables}

The independent variables of the study that is cognitive, behavioral and environment learning experience were related to internship. That is cognitive learning experience, CLE (seven items: $\alpha=0.806$ ); the behavioral learning experience, BLE (seven items: $\alpha=0.809$ ); and the environmental learning experience, ELE (seven items: $\alpha=0.524$ ). The items per mentioned variable were Likert scaled in such a way that: $1=$ "Strongly disagree", 2 = "Disagree", 3 = "Undecided", 4 = "Agree" and 5 = "Strongly agree". Table 2 presents the pertinent results:

Table 2 presents the computed overall aggregates from the item clusters of each of the independent variables. The respondent's ratings of each of the units that is; cognitive learning experience, CLE (Mean = 4.10) behavioral learning experience, BLE (Mean = 4.32) and environmental learning experience, ELE (Mean $=4.26$ ) which show a general acceptance of the competences acquired in line with each unit. These results were supported by the respondents' rating and comments from the second set of respondents as presented in Table 3 . 
Table 2

Statistics on the Independent Variables

\begin{tabular}{|c|c|c|c|}
\hline & Mean & Remark & $\begin{array}{l}\text { Overall } \\
\text { remark } \\
\text { Internship }\end{array}$ \\
\hline \multicolumn{4}{|l|}{ Indicators of the CLE of Internship } \\
\hline The internship helped me to reflect on my career planning & 4.26 & Agree & \multirow{7}{*}{$\begin{array}{l}\text { Mean =4.10 } \\
\text { (Agree) }\end{array}$} \\
\hline The internship aroused my interest in the expertise of transforming communities & 3.83 & Undecided & \\
\hline The internship experience enabled me to start looking at different angles in tackling issues & 4.30 & Agree & \\
\hline $\begin{array}{l}\text { The internship aroused my ambition to gain an in depth understanding of the knowledge } \\
\text { relevant for rural transformation }\end{array}$ & 3.74 & Undecided & \\
\hline $\begin{array}{l}\text { The internship helped me to have a better understanding in interpreting and evaluating } \\
\text { challenges as they unfold }\end{array}$ & 4.17 & Agree & \\
\hline $\begin{array}{l}\text { The internship provided me with the necessary information and experience to choose the right } \\
\text { venture/s for the transformation of the epicenter }\end{array}$ & 4.00 & Agree & \\
\hline Generally the internship experience contributed significantly towards my knowledge base & 4.39 & Agree & \\
\hline \multicolumn{4}{|l|}{ Indicators of BLE of Internship } \\
\hline The affirmation of community members made me feel a strong sense of accomplishment & 4.22 & Agree & \multirow{7}{*}{$\begin{array}{l}\text { Mean }=4.32 \\
(\text { Agree) }\end{array}$} \\
\hline I believe that the internship experience will help me find a job & 4.22 & Agree & \\
\hline The internship provided me with hands on practice and exposure & 4.57 & $\begin{array}{l}\text { Strongly } \\
\text { agree }\end{array}$ & \\
\hline The internship enabled me to put the classroom theory to practice & 4.30 & Agree & \\
\hline The internship improved my confidence and self-esteem & 4.23 & Agree & \\
\hline The internship helped me develop communication skills & 4.35 & Agree & \\
\hline The internship helped me to develop interpersonal skills & 4.35 & Agree & \\
\hline \multicolumn{4}{|l|}{ Indicators of ELE of Internship } \\
\hline The community strengthened and sometimes formed my ideas on various socio-economic issues & 4.09 & Agree & \multirow{7}{*}{$\begin{array}{l}\text { Mean }=4.26 \\
(\text { Agree })\end{array}$} \\
\hline $\begin{array}{l}\text { The norms of the community informed the internship activities (schedules for meetings, home } \\
\text { visits etc.) }\end{array}$ & 4.43 & Agree & \\
\hline The community strengthened my abilities and improved my values & 4.17 & Agree & \\
\hline $\begin{array}{l}\text { The internship gave me the desire to influence the people around me to transform their lives } \\
\text { and homes }\end{array}$ & 4.57 & $\begin{array}{l}\text { Strongly } \\
\text { agree }\end{array}$ & \\
\hline The internship increased my tolerance and patience for the management of tasks and work & 4.48 & Agree & \\
\hline $\begin{array}{l}\text { Interacting with community members changed my original living style including dressing, } \\
\text { interaction with peers etc. }\end{array}$ & 3.68 & Undecided & \\
\hline $\begin{array}{l}\text { The internship prepared me better in the utilization of locally available resources for } \\
\text { community development }\end{array}$ & 4.39 & Agree & \\
\hline
\end{tabular}

Table 3

Statistics on Community Assessment

\begin{tabular}{|c|c|c|c|}
\hline & Mean & Remark & $\begin{array}{l}\text { Overall } \\
\text { remark }\end{array}$ \\
\hline \multicolumn{4}{|l|}{ Cognitive analysis } \\
\hline Interns has knowledge of subject matter & 4.28 & Agree & \multirow{8}{*}{$\begin{array}{l}\text { Mean }=4.26 \\
\text { (Agree) }\end{array}$} \\
\hline Intern always starts with objectives which are stated clearly and are met & 4.08 & Agree & \\
\hline Intern encourages community members to give their opinions & 4.49 & Agree & \\
\hline Intern is well organized in her work & 4.38 & Agree & \\
\hline Intern evaluates the activities initiated & 4.00 & Agree & \\
\hline Creativity while working & 4.42 & Agree & \\
\hline Use of locally available materials (improvisation) & 4.33 & Agree & \\
\hline Looks at different angles while tackling issues & 4.09 & Agree & \\
\hline
\end{tabular}


Table 3 continued

\begin{tabular}{llll}
\hline & Mean & Remark & $\begin{array}{l}\text { Overall } \\
\text { remark }\end{array}$ \\
\hline Behavioral analysis & & \\
\hline Practices hands-on activities (walks the talk) & 4.34 & Agree \\
Follows up (monitors) the activities initiated & 4.21 & Agree \\
Punctuality & 4.30 & Agree \\
Sets deadlines & 4.88 & Strongly & Mean $=4.31$ \\
Meets deadlines & agree & (Agree) \\
Dresses decently & 4.10 & Agree & \\
Regularity at work place & 4.47 & Agree \\
\hline Environmental analysis & 3.88 & Undecided \\
\hline Interest in working with communities & & \\
Works well with community leaders & 4.34 & Agree \\
Intern encourages participation of community members and respects their opinions & 4.30 & Agree \\
Has mobilization skills & 4.38 & Agree & Mean $=4.31$ \\
Able to identify community needs for interventions & 4.36 & Agree & $($ Agree) \\
Willingness to volunteer & 4.28 & Agree
\end{tabular}

According to Table 3, the overall aggregates (CLE, BLE, and ELE) confirmed the views of the key respondents that is; the general acceptance that there competences acquired from internship with a mean of 4.26 under cognitive analysis, 4.31 for behavioral analysis and 4.31 for environmental analysis. These pointed to a general agreement on the competence ratings of the key respondents.

\section{Statistical Model for Predicting Internship Using the Independent Variables}

The multiple regression analysis of the internship index (IAF from Table 1) on the three independent variables, IVs (CLE, BLE, and ELE from Table 2), that is Expression (1),

$$
\begin{gathered}
\mathrm{IAF}=0.014 \mathrm{CLE}+0.059 \mathrm{BLE}+0.773 \mathrm{ELE} \\
(0.729)(0.845)(0.079),
\end{gathered}
$$

with $F=4.455, p=0.021$ and the Adjusted $R$-square $=0.379$. The figures below the respective coefficients in Expression (2) were the pertinent $p$-values. The Model in Expression (2) suggested that the three independent variables considered were collectively good explanatory variables $(F=4.455, p=0.021)$ of Internship at the one percent level of significance ( $p<0.01$ ), accounting for $37.9 \%$ of the variation in the aggregate internship index (Adjusted $R$-square $=0.379$ ). Expression $(2)$ further suggested that all the three Independent Variables were not correlates of Internship since all their $p$ s were greater than $0.05(p<0.05)$ thus CLE (Beta, $\beta=0.014$; $p=0.729) \operatorname{BLE}(\beta=0.059 ; p=0.845)$ and $\operatorname{ELE}(\beta=0.773 ; p=0.079)$. The three hypotheses (H1 through H3) therefore were rejected.

\section{Discussion}

The three hypotheses (H1 through H3) to the effect that, cognitive, behavioral and environmental learning experiences were positively related to internship were not supported. In respect to H1, the findings were contrary to studies (e.g., Cord et al., 2010; Lievens \& Sackett, 2012; Jones, 2012; Cooper, 2013; Ralph \& Walker, 2014) which positively related Cognitive learning experience to internship. The results to the second hypotheses (H2) also differed from the findings of several researchers that found behavioral learning 
experience to be related to positively related to internship in different contexts (e.g., Rusnah et al., 2009; Cord et al., 2010; Lievens \& Sackett, 2012). Contrary results were further registered by several studies (e.g., D'abate et al., 2009; Kuijpers et al., 2010; Chen \& Chen, 2011; Jones, 2012; Cooper, 2013) in respect to hypotheses three (H3) since they found environmental learning experience to be positively related to internship.

Several issues could be responsible for such unexpected results that is: nature of the units of analysis, sample size and context. Apart from the fact that this was a maiden study, for pioneer students in respect to the context that was totally different from that of the cited studies, the sample size was also small compared to the studies in comparison. However, the findings on H1 were consistent with studies (e.g., Rusnah et al., 2009; Chen \& Chen, 2011) that did not find cognitive learning experience to be a correlate of internship. The findings on $\mathrm{H} 2$ also joined the category of earlier studies that did not find a correlation between behavioral learning experience and internship, study (e.g., Chen \& Chen, 2011) yet the findings on H3 were also consistent with findings of studies (e.g., Rusnah et al., 2009; Kamulegeya et al., 2012) that did not find a correlation between environmental learning experience and Internship.

The results of the study therefore imply that in the quest to enhance the effectiveness of internship in fostering learning, the key players in the university that's to say: the Academic Registrar, Dean of Faculty, the faculty at large ought to strengthen the existing salient features to internship but bearing in mind that there other important aspects that point towards the boosting of the relevance of internship to students for the benefit of all. Issues of student's interest into what they do, the length of internship, the role of local government leaders and the community at large, the mentor and mentee relationship among other aspects ought to be given due consideration.

\section{Conclusion}

Under the pretext that learning takes place beyond the confines of the classroom, Cheong, Yahya, Shen, and Yen (2013), internship ought to be given greater focus since it gives students chance to see the bigger picture and to be more independent in their areas of specialization. In particular, the ARU one year internship is a perfect fit for students to put the dully acquired three year theory into practice among other benefits that accrue to both the student and the institution. This study sought to build a statistical model that could predict the effectiveness of internship to undergraduate students of ARU using the constructs of the social cognitive theory (SCT) that is: cognitive, behavioral and environmental aspects. In so doing, the study closed several gaps that is: it was the pioneer in relating the constructs of SCT to internship in ARU, it was also the pioneer in considering undergraduates as the units of analysis in respect to internship among other aspects.

The multiple regression model revealed that while all three independent variables (CLE, BLE and ELE) were collectively good predictors of internship, the three were found not to be correlates of the dependent variable (DV) Internship. The results therefore imply that the relevant change agents in the university should not lay undue emphasis on enhancing cognitive, behavioral and environmental aspects to internship in respect to the undergraduate interns rather identify and work towards the improvement of internship in respect to identified accrued factors to it for the benefit of all concerned parties.

Despite the contributions of the study, there were key limitations too. For example, this study dealt with a small sample size, though not out choice, one could do the same study in a context with a bigger population to contribute to the sample. Other suggested areas for future research include conceptual issues where other variable could be used in the same or other contexts. However despite the shortcomings, the study has 
contributed to the knowledge base of the university and the academia in general. It will be a basis on to which future researchers will build in respect to issues of internship and learning.

\section{References}

African Rural University. (ARU, 2014/2015). Technologies for rural transformation students' internship programme. Retrieved from http://www.aru.org/10.155tl/cs04-11-13cc

Atwaru, D. O. (2014). Review of the curriculum for technologies for rural transformation curriculum (Unpublished Concept Paper, African Rural University).

Bama, N. K., \& Issy, U. T. (2013). Evaluating graduate employability in Cape Town with reference to the environmental internship programme. Entrepreneurship and Innovation Management Journal, 1(1), 105-114.

Bandura, A. (2011). Social cognitive theory: Handbook of social psychological theories. London, Sage.

Bukaliya, R. (2012). The potential benefits and challenges of internship programmes in an ODL institution: A case for the Zimbabwe Open University. International Journal of New Trends in Education and Their Implications, 3(1), 118-133.

Chen, C. T., \& Chen, C. F. (2011). The influence of internship experience on the behavioral intention of college students in Taiwan. The Asian Pacific Education Researcher, 20(1), 73-92.

Cheong, A. L. H., Yahya, N. B., Shen, Q. L., \& Yen, A. Y. (2013). Internship experience: An in-depth interview among interns at a Malaysian Private Higher Learning Institution. Social and Behavioral Sciences, 123, 333-343.

Chinomona, R., \& Surujhal, J. (2012). The influence of student internship work experience on their self-improvement and professionalism in sports management. African Journal of Physical Health Education, Recreation and Dance (AJPHERD) 18(42), 885-899.

Cooper, L. Z. (2013). Student reflections on an LIS internship from a service learning perspective supporting multiple theories. Journal of Education for Library and Information Science, 54(4) 286-304.

Cord, B., Bowrey, G., \& Clements, M. (2010). Accounting student's reflection on a regional internship programme. Australasian Accounting Business and Finance Journal, 4(3), 47-64.

D'abate, C. P., Youndt, M. A., \& Wenzel, K. (2009). Making the most of an internship: An empirical study of internship satisfaction. Learning and Education, 8(4), 527-539.

Denler, H., Wolters, C., \& Benzon, M. (2014). Social cognitive theory: The glossary of education reform. Education.com

El Tawil, M. S., Al Khal, A. L., Ahmed, S. A., \& Helmi, I. (2011). The impact of Traditional rotating internship on cognitive skills of trainees. International Journal of Academic Research, 3(2), P124.

Jones, J. (2012). An analysis of learning outcomes with in formal mentoring relationships. International Journal of Evidence Based Coaching and Mentoring, 10(1), 57-72.

Kamulegeya, A., Kizito, A. N., \& Balidawa, H. (2012). Uganda medical and health science interns' infection control knowledge and practice. J. Infect Dev. Ctries, 7(10), 726-733.

Kuijpers, M., Meijers, F., \& Gundy, C. (2010). The relationship between learning environment and career competences of students in vocational education. Journal of Vocational Behavior, 78(1), 21-30.

Lamberth, G. (2010). Environmental learning and experience. Education.com

Lievens, F., \& Sackett, P. R. (2012). The validity of interpersonal skills assessment via situational judgment tests for predicting academic success and job performance. Journal of Applied Psychology, 97(2), 460-468.

Muthaura, P. N., \& Khamis, T. K. (2013). The perceptions of the preparedness of medical graduates to take on internship responsibilities in low resource hospitals in Kenya. Journal of Higher Education Studies, 3(1), 115-122.

Nebavi, R. T. (2012). Bandura's social learning theory and social cognitive learning theory. University of Science and Culture, Tehran, Iran.

Neugebauer, J. (2009). Investing in the future: The essential role of student placements. Center for Employment Studies Research (CESR), University of West England, Bristol.

Papadimitriou, M. (2014). High school student's placements of their internship experience and related impact on career choices and change. On line Journal of Workforce Education and Development, 7(1), 1-28.

Ralph, E. G., \& Walker, K. D. (2014). Mentorship in the practicum: Post intern's perspective. International Journal of Humanities and Social Sciences, 4(8), 1-10.

Rusnah, M., Yazkhiruni, Y., Suhaily, S., \& Nurmazilah, M. (2009). Undergraduate internship attachment in accounting: The interns' perspective. International Education Studies, 2(4), 49-55. 
Sincero, S. M. (2011). Cognitive learning theory. Retrieved October 2, 2015, from http://explorable.com/cognitive-learningtheory

Steffen, H. (2010). Student's internship and the privilege to work. Cultural Logic, ISSN 10-97-3087.

Tavakol, M., \& Dennick, R. (2011). Making sense of Cronbach alpha. International Journal of Medical Education, 2, 53-55.

Taylor, S., \& Govender, C. (2013). Education and training for the work place: Work place readiness skills. Work Integrated Learning and Employability, South Africa.

Uganda Rural Development and Training Programme. (URDT, 2013). The Epicenter Strategy for Implementing Uganda Vision 2040: "A transformed Ugandan society from a peasant to a modern and prosperous country within 30 years".

Zhou, M., \& Brown, D. (2014). Educational learning theories. Creative Commons Attribution 4.0. 